\title{
EAST TIMOR AND THE INTERNET: GLOBAL POLITICAL LEVERAGE IN/ON INDONESIA'
}

David T. Hill

"The political clarity of contemporary humanitarian imperatives, in the face of traditional appeals to national interest, highlights an important emerging new feature of international relations: the pivotal role that can be played by civil society armed with new technologies of communication."2

\section{Introduction}

Student protestors inside the occupied national Parliament compound reporting online to the world from laptop computers epitomized the extent to which forces opposing President Suharto mobilized the internet in the dying phase of his rule. ${ }^{3}$ So

\footnotetext{
${ }^{1}$ Research for this paper was part of a broader project on "The Internet and Democracy in Indonesia," funded by an Australia Research Council Grant and undertaken jointly with Krishna Sen (Curtin University, Western Australia), who has contributed enormously to my understanding of this topic, but who shares no responsibility for this particular paper's many shortcomings. I would like to thank Professor Ben Arps, who convened a symposium "Media Cultures in Indonesia/Budaya Media di Indonesia" at Leiden University in April 2001, at which an early draft was presented. Thanks also to Herb Feith, John Waddingham, and Charles Scheiner for valuable comments on earlier versions. All responsibility for the many remaining limitations is mine.

2 Wade Huntley and Peter Hayes, "East Timor and Asian Security," in Bitter Flowers, Sweet Flowers: East Timor, Indonesia, and the World Community, ed. Richard Tanter, Mark Selden, and Stephen R. Shalom (Sydney: Pluto Press Australia, 2001), pp. 173-188 (quotation from p. 183).

${ }^{3}$ See, for example, the chapter "The Internet: Virtual Politics," in Krishna Sen and David T. Hill, Media, Culture and Politics in Indonesia (Melbourne: Oxford University Press, 2000), pp. 194-217.
} 
too, under Suharto's successors, is the internet proving a new medium for separatist and minority ethnic groups within the archipelago seeking self-determination or international recognition for their aspirations. "The most important factor in gaining independence is communication with international powers," claimed one Acehnese separatist leader, who added, "The Internet is the only way we can achieve this."4 They are staking their claim on the internet, with several sites like "Achehnese tears" providing "information on breaches of human rights in Aceh," complete with graphic photographs of military brutality..$^{5}$ Moluccan groups, too, both in Indonesia and abroad, have taken to the internet to argue their position on the recent conflict there. ${ }^{6}$ This paper examines how one particular marginalized regional independence movement has exploited the potential of the internet in its struggle. East Timor ${ }^{7}$ provides a striking example of how a protracted independence struggle adjusted to the new strategic possibilities of the internet, how these new technological possibilities could exert international political leverage, and how they can be applied by a nation on the path to independence.

Much has been written about the movement for an independent East Timor. ${ }^{8}$ Less analysis has focused on the strategies, and particularly the technologies, employed in the international diplomatic lobbying that accompanied the local guerrilla resistance. ${ }^{9}$ Writings abound on the history and use of the internet. Less commonly has attention strayed to the history, and the incorporation, of internet technologies within specific states beyond North America and Europe, within the context of particular social and political conflicts. This paper is not a detailed history of the local struggle in East Timor, but will attempt to plot the incorporation of internet (and related) technologies into that struggle. It then discusses how the internet provided a unique opportunity for East Timor to claim "independence in cyberspace" as part of a spectrum of internet-

\footnotetext{
${ }^{4}$ Muhammad Nazar, the chairperson of Sira, an Acehnese group pressing for a self-determination referendum, is quoted in "Dateline-Internet: A virtual front line," AsiaWeek, June 21, 2001, located via http://web3.infotrac.galegroup.com/itw (accessedAugust 3, 2001).

5 At http://members.tripod.com/Achehnese (accessed September 2, 1999).

${ }^{6}$ In "Consumers as Citizens in the Information Economy: Notes on the Internet in Indonesia" (forthcoming 2002), Krishna Sen and I look at a Moluccan e-group, AMBONnet.

${ }^{7}$ From July 17, 1976 to October 20, 1999, the disputed territory of East Timor was claimed by Indonesia as its twenty-seventh province. The United Nations (Decolonization Committee, Security Council or General Assembly) never recognized this annexation into Indonesia. Indonesia relinquished its claims after 78.5 percent of the East Timorese effectively voted in favor of independence (by rejecting the Indonesian offer of autonomy) in a United Nations-sponsored "Popular Consultation" on August 30, 1999. The name for the territory in the Tetun lingua franca is Timor Loro Sa'e, but the more common English "East Timor" is used throughout this paper.

${ }^{8} \mathrm{~A}$ brief bibliography of material related to East Timor appears on http://www.ci.uc.pt/Timor/bibhtml.htm (accessed August 10, 2001). This does not include the numerous books published in Australia about East Timor since the August 30, 1999 referendum, several of which are cited later in this paper.

${ }^{9}$ See Grayson J. Lloyd, "The Diplomacy on East Timor: Indonesia, the United Nations and the International Community," in Out of the Ashes: Destruction and Reconstruction of East Timor, ed. James J. Fox and Dionisio Babo Soares (Adelaide: Crawford House Publishing, 2000), pp. 79-105. Lloyd provides an overview of the diplomatic negotiations, but does not comment on the technologies employed. Similarly, Eilís Ward and Peter Carey, "The East Timor Issue in the Context of EU-Indonesian Relations, 1975-99," Indonesia and the Malay World 29,83 (2001): 51-74.
} 
related activist strategies, sometimes dubbed "hactivism." In the final section, the paper traces the role of the internet and other new technologies in the months before and after the August 30, 1999 United Nations-sponsored referendum.

The study is thus an attempt at a(n albeit partial) technological history of East Timor's resistance movement, examining how political strategies and the new telecommunication technologies converge in the service of the struggle. This examination supports the fundamental argument that it is not the technology of the internet that ultimately determines its political possibilities, but the particular local political contexts to which the internet is brought to bear. As Huntley and Hayes have argued, in the hands of civil society, such technologies now play a pivotal role in international relations.

\section{The Battle for Information}

East Timor's independence struggle can be plotted alongside the history of the new computer-mediated technologies themselves. On October 6, 1975, in the year Bill Gates and Paul Allen licensed their BASIC computer language and founded Micro-Soft (before they dropped the hyphen), Indonesian "volunteers" attacked the East Timor border region village of Batugade. The year 1975 thus marked both the birth of the personal computer revolution that formed the basis of the internet's open future ${ }^{10}$ and, for East Timor, the beginning of one of the most brutal covert international invasions of the second half of the twentieth century. It was not until two months later, on December 7, 1975, that Indonesian forces officially entered East Timor; this operation took place barely a week after the primary pro-independence party, Fretilin, declared the territory's independence on November 28. But, within ten days of the initial October 6 attack by Indonesian irregulars on Batugade, five Australia-based journalists had been targeted and killed in the aftermath of an assault on Balibo by a "mixed force of 3,600 Kopassanda (Indonesian commandos) and Timorese supporters."11

Australian Labor Prime Minister Gough Whitlam heard of the murders within about ten hours from Australian intelligence agencies monitoring Indonesian military signals. But having been informed the same day that the Liberal opposition in the Parliament's upper house planned to block supply of monies to his government and starve it of funds, Whitlam and his senior ministers accepted intelligence advice that they refrain from publicly admitting knowledge of the deaths. The Indonesian military was determined to control the flow of information out of East Timor, and it happened that neighboring governments, most notably Australia's, colluded in helping them maintain this silence, for they routinely withheld intelligence in their possession unless such information had become public through other means. For much of the next

${ }^{10}$ See C. J. P. Moschovitis, H. Poole, T. Schuyler, and T. M. Senft, History of the Internet: A Chronology, 1843 to the Present (Santa Barbara: ABC-CLIO, 1999), particularly Chapter 3.

11 A summary detailing Australian government knowledge of the attack on Balibo is given in East Timor: Final Report of the Senate Foreign Affairs, Defence and Trade References Committee (Canberra: The Parliament of the Commonwealth of Australia, December 2000), pp. 133-135. The most revealing analysis of this event can be found in Desmond Ball and Hamish McDonald, Death in Balibo, Lies in Canberra (St. Leonards: Allen \& Unwin, 2000). 
twenty-four years, in their public posture, successive Australian governments appeared not to know anything unless the Indonesian government made it public first. The belated media revelation of the journalists' fate focused international attention on this largely unreported half-island and insured that the media-at least the Australian media-was periodically to return to the subject for the next quarter century. ${ }^{12}$ These deaths were but one of several reasons why Australia was to play a leading role in international public and media coverage of East Timor. Simple proximity, together with a historical memory of the sacrifice paid by East Timorese protecting Australian soldiers against Japanese attacks in World War II, also helped draw the attention of the Australian media to East Timor, as did the presence in Australia of a growing East Timorese refugee community.

The logistics faced by the five ill-fated journalists illustrated how difficult communications were in 1975 . "The only way of getting a message out of Balibo was for someone to carry it by road," wrote Desmond Ball and Hamish McDonald, as the

Fretilin troops in Balibo had no radio. There was no telephone line. From Maliana [twenty kilometers east and forty-five minutes by road] a single phone line ran to another town further into East Timor, from where telephone calls were relayed by radio link to Dili. Maliana also had Fretilin's nearest radio post. A telephone service also linked Atabae, on the north coast, with Dili, but this town was several hours drive from Balibo. ${ }^{13}$

In the months preceding the Indonesian invasion, Fretilin's military wing, Falintil, maintained its own radio communications network, but made extensive use of the civilian telephone network (which used some wire connections, but mainly radio relay), both of which were subject to interception by Indonesian military signals intelligence. ${ }^{14}$

During the next twenty-four years of struggle against Indonesian occupation, the primary strategic concern of the East Timorese pro-independence guerrillas was survival against a far stronger and better-equipped occupation force. The guerrillas were supported by their designated representatives abroad, notably José RamosHorta, who, since his arrival at the United Nations Organization in New York on December 11, 1975, traveled the world to maximize international protest against the Indonesian invasion of East Timor. The movement was supported abroad by a committed, if sometimes chaotic, array of sympathetic groups, non-governmental organizations, and individuals, who agitated on behalf of self-determination for East

12 A chronology of events relating to East Timor for the years 1974-1976 is given in Wendy May, ed., Documents on Australian Foreign Policy: Australia and the Indonesian Incorporation of Portuguese Timor, 1974-1976 (Melbourne: Department of Foreign Affairs and Trade \& Melbourne University Press, 2000), pp. xvii-xxix. The Australian Broadcasting Commission broadcast initial reports of the journalists "missing in the region" on the morning of October 17, 1975; other outlets quickly took up the story, particularly TV Channels 7 and 9, employers of the missing journalists. In Indonesia Kompas first reported the deaths on October 20. See May, Documents on Australian Foreign Policy, pp. 479, 481, 491. For a study of how the Australian media covered East Timor, see Rodney Tiffen, Diplomatic Deceits: Government, Media and East Timor (Sydney: University of New South Wales Press, 2001).

13 Ball and McDonald, Death in Balibo, pp. 44-45.

${ }^{14}$ Ibid., pp. 55-64. This source provides details of Fretilin and Falintil communication methods and Indonesian interception of these during October 1975. 
Timor. During at least the first fifteen years of their campaign, a crucial challenge for such activists was securing access to information about what was happening in East Timor itself. ${ }^{15}$

It was an often insurmountable challenge, for "Few countries in the contemporary era have been so hermetically sealed as East Timor was in the years following the invasion."16 Pro-independence forces experienced considerable difficulty in communicating with the outside world-or even broadcasting information within East Timor. Dili's civilian telecommunications hub, the Marconi Center, was one of the first targets for destruction by the invading forces. The local Dili radio station, which had been broadcasting as Radio Fretilin or Radio Maubere, was quickly captured by Indonesian forces, whose broadcast announced: "Fretilin is no more. Radio Maubere is dead ... Long live the people of East Timor with the Republic of Indonesia!"17 Several American-made World War II portable radio transceivers, left by the Portuguese Army, together with some later model pack radios, and transceivers supplied several weeks earlier from Darwin by Australian sympathizers, ${ }^{18}$ were carried off by the guerrilla forces. Despite constant difficulties maintaining these mobile radio units, they were capable of transmitting to northern Australia from the resistance's mountain retreats and were used regularly for messages over three years. The messages to Australiawhich, when necessary, were sent using a primitive (and ultimately ineffective) code in an attempt to maintain secrecy-were then taped, transcribed, and either phoned (or, from March 1976, telexed) to key Fretilin contacts in Mozambique, Portugal, and elsewhere. (This painstaking and expensive procedure contrasted starkly with the efficiency of the instantaneous, secret transmissions possible after the adoption of encrypted e-mail in the early 1990s.) The efficacy of the radio link depended on the existence of mobile radio reception and transmission equipment being used by the Campaign for an Independent East Timor (CIET) in Australia's Northern Territory. While it was permissible to receive messages, it was illegal to transmit from Australia without a license, which the Australian government steadfastly refused to issue. Instead, after a long-running cat-and-mouse chase, the government eventually succeeded in confiscating the CIET equipment. Within East Timor, the surrender in December 1978 of Fretilin's minister for information and internal security led to the seizure of Fretilin's transmission equipment and the severing of its vital radio link to the world outside. ${ }^{19}$

Pro-independence forces had other ways of circumventing the Indonesian government's blanket of silence over East Timor, including through family or church contacts. Throughout the 1980s, following the cessation of radio contact, letters and messages detailing human rights abuses and military clashes (which were sometimes scrawled on the torn-out pages of school exercise books) were smuggled out of the territory. Once information had been secreted out of East Timor, international support

\footnotetext{
15 Personal communication with John Waddingham, co-founder/editor of Timor Information Service (Australia), (1975-84), by telephone, Perth, March 12, 2001.

16 Tiffen, Diplomatic Deceits, p. 27.

17 Quoted in Ball and McDonald, Death in Balibo, p. 177.

18 This supply and maintenance of radio contact during 1975-78 is vividly described in Denis Freney, $A$ Map of Days: Life on the Left (Melbourne: William Heinemann Australia, 1991), pp. 354-373.

19 Ball and McDonald, Death in Balibo, pp. 177-180.
} 
groups actively disseminated it through any means available, to the media, to sympathizers, and to like-minded political organizations around the world. Such material occasionally made it into the mass media, but its veracity was questioned by the Indonesian government. ${ }^{20}$ Third-party verification was virtually impossible. As new technologies became available, they were readily used. A small number of satellite phones was smuggled into the territory. One, reportedly brought into the territory by a Japanese activist, was used by Falintil Commander Konis Santana ${ }^{21}$ (until it broke in 1995). Maintenance of equipment was a constant problem.

However, the "opening up" of East Timor by the Suharto regime in January 1989 did facilitate greater flow of information and intrepid investigators across the borders. ${ }^{22}$ The first demonstration to capture international media attention took place when banners were unfurled at an open-air Mass being celebrated by Pope John Paul during a visit to Dili in October 1989. One striking success was Robert Domm's September 1990 interview with the leader of the National Council of Maubere Resistance (CNRM) in the mountains of Ainaro; this interview introduced Xanana Gusmão to the outside world and demonstrated that the resistance movement had a powerful intelligence apparatus capable of outwitting its Indonesian counterpart. ${ }^{23}$

During the years of East Timor's imposed silence, computer-mediated communication technology was advancing steadily. In 1979, the first two American campuses were linked via phone line by Usenet, "a multidisciplinary computer network of news and discussion groups." Within a few years, Usenet connections extended to Europe and Australia, and the subject-based "newsgroups" organized on the Usenet grew to cover an ever-wider range of topics, although most of the sixty thousand Usenet users were still in military installations, universities, or technology corporations. By the time Indonesia "opened up" East Timor in 1989, civilian networks were emerging that allowed a general consumer, using a common networking protocol (known as $\mathrm{TCP} / \mathrm{IP}^{24}$ ), to create what was collectively known as the "internet." 25 In 1990, the newsgroup "reg.easttimor" was started by several activists and human rights groups, using the Alliance for Progressive Communications (APC) system as a medium. APC (which included member networks such as PeaceNet and

${ }^{20}$ I would like to thank Pat Walsh, formerly of the Australian Council for Overseas Aid, for discussing the methods used by Australian supporters of an independent East Timor, March 13, 2001.

21 Konis Santana was field commander of Falintil, the military arm of the resistance movement, until his accidental death in late 1997. See John Martinkus, A Dirty Little War (Sydney: Random House Australia, 2001), p. 244.

22 On the opening up of 1989-91, see Herb Feith, "East Timor: The Opening up, the Crackdown and the Possibility of a Durable Settlement," in Indonesia Assessment 1992: Political Perspectives on the 1990s, ed. Harold Crouch and Hal Hill, Political and social change monograph No. 17 (Canberra: ANU, 1992), pp. 6380 .

23 Domm entered East Timor briefly in January 1989, very soon after the territory was opened up to visitors, and returned again in September 1990 to interview Gusmão for the Australian Broadcasting Corporation's "Background Briefing" radio program. See Mark Aarons and Robert Domm, East Timor: $A$ Western Made Tragedy (Sydney: New Left Book Club, 1992), and Tiffen, Diplomatic Deceits, pp. 51-52.

24 TCP/IP refers to "Transmission Control Protocol/Internet Protocol" which drives the internet. See Angus J. Kennedy, The Rough Guide to the Internet (London: Rough Guides, 2000), p. 481.

25 Moschovitis et al., History of the Internet, pp. 109, 126. 
GreenNet) "provided the wires, but the initiative, content, and promotion was all done by NGOs and individuals," including Tapol: The Indonesian Human Rights Campaign in the UK and groups in the USA which later coalesced in the East Timor Action Network (ETAN/US). ${ }^{26}$ This facility enabled e-mailed information about the East Timor situation to be disseminated around the world to like-minded organizations. In Australia and elsewhere, key activists were beginning to recognize the potential of this technology. By 1991, Usenet was hosting more then 35,000 nodes, producing nearly ten million words of discussion daily. ${ }^{27}$

In another path-breaking innovation, researchers in the European Laboratory for Particle Physics (CERN) revolutionized the linkage, storage, and retrieval of information (using HTTP, HTML, and URL as building blocks ${ }^{28}$ ). From its introduction in 1991, this system, called the World Wide Web (WWW), together with the "browsers" and "search engines" that soon followed, enabled users to gain rapid access to vast, virtually unlimited, amounts of data. Once information was entered on the internet, the WWW made possible rapid retrieval from any linked computer. ${ }^{29}$ The internet had become, in the term popularized by future US vice-president Al Gore in 1990, an "Information Superhighway." Its application grew exponentially; use of the original WWW server at CERN increasing tenfold per annum between 1991 and $1994 .^{30}$ By 1994 , the underground resistance was beginning to use e-mail from inside East Timor, corresponding clandestinely to avoid detection by the Indonesian military. For the most part, however, the fledgling technology remained rare within East Timor; in the early 1990s, more conventional methods were generally being used to pass on information (and matériel) between the guerrillas and underground supporters in Indonesia (like the National Resistance of East Timorese Students, RENETIL, founded in 1986) and abroad (like the various human rights and East Timor lobby groups). ${ }^{31}$ Even internationally, for the vast majority of independence supporters, "snail mail," fax, and phone remained the most common means of communication.

The Indonesian government's gradual enhancement of the telecommunications infrastructure in the territory provided some benefits for those wishing to breach the

${ }^{26}$ Charles Scheiner, personal communication, September 7, 2001. Scheiner was one of the founding sponsors of reg.easttimor.

27 Moschovitis et al., History of the Internet, pp. 102-103.

${ }^{28}$ HTTP ("Hyper-Text Transfer Protocol") is for web text transfer, while HTML ("Hyper-Text Markup Language") is used to make web documents, and URL ("Uniform Resource Locator") is the formal name for a Web address.

${ }^{29}$ Moschovitis et al., History of the Internet, p. 127.

30 Ibid., p. 153.

31 For a graphic description of the underground in East Timor and its links with sympathizers abroad, see Constâncio Pinto and Matthew Jardine, East Timor's Unfinished Struggle: Inside the Timorese Resistance (Boston: South End Press, 1997), particularly pp. 92-134. On RENETIL, see Quentiliano Mok, "The Role of RENETIL: National Resistance of East Timorese Students," in East Timor Relief Association (ETRA), It's Time to Lead the Way (Collingwood: ETRA, 1996), pp. 106-108. For a more comprehensive list of underground resistance groups, see Donaciano Gomes, "Resistance: Twenty Years of Struggle Supported by Young East Timorese," in ETRA, It's Time to Lead the Way, pp. 115-120. Member organizations of the International Federation for East Timor (IFET) are listed at http://etan.org/ifet/member.html, while an updated "List of East Timor Support and Solidarity Groups Worldwide" is at http:/ /etan.org/ifet/support.html (accessed August 29, 2001). 
information cordon. Corroborating details of the November 12, 1991 Santa Cruz massacre were transmitted out of East Timor by telephone calls to supporters and international aid organizations like the Red Cross in Jakarta and elsewhere, reinforcing reports from foreign journalists who had fled East Timor after witnessing the massacre. ${ }^{32}$ Accounts were subsequently disseminated around the world via newsgroups like "reg.easttimor" and mailing lists like John MacDougall's apakabar. ${ }^{33}$ But it was the potent images of the massacre filmed in the cemetery on a micro-camera by Max Stahl, the striking photographs by Steve Cox, and the vivid descriptions by journalist Allan Nairn, that distilled the brutality of East Timor into a single graphic event for the international mass media. Cut into sound bites, screened repeatedly around the world, Stahl's footage of the Santa Cruz massacre reinvigorated the proindependence movement abroad and brought the campaign back into the mainstream mass media. In the words of Jakarta-based Australian journalist Michael Maher,

The capturing of this atrocity on film represented a major turning point for East Timor. No longer could the leaders of the Western world conveniently turn a blind eye to the suffering in this remote half-island perched on the outer reaches of the Indonesian archipelago. Stahl's footage defied them to turn away. ${ }^{34}$

The profiling of Xanana Gusmão, his capture by Indonesian forces in November 1992, and subsequent trial attracted further media attention. ${ }^{35} \mathrm{He}$ provided a sharp focus for both television and press coverage. From his Jakarta prison he was able to maintain his contacts with the independence struggle outside (aided by a mobile phone secreted into the jail). Select key supporters were given intensive training in the use of computer-mediated communications technologies overseas from a computer expert who had been involved in setting up the "minihub.org" network for the use of civil society organizations. With such skills, Gusmão's supporters in Jakarta could then send e-mail messages using "PGP" ("Pretty Good Privacy") encryption 36 to East Timorese contacts abroad, such as Ramos-Horta. Until local ISPs (Internet Service Providers) were established in Indonesia, these activists logged on to the internet by dialing internationally, usually to Pactok, a low-cost electronic mail network for NGO movements in the Asia-Pacific region set up in 1991. Internet correspondence, which could be handily encrypted, offered users greater peace of mind than telephone

32 Amy Goodman and Allan Nairn escaped to Guam the day of the massacre and carried out phone and other kinds of interviews with world media from there.

33 On apakabar, see Sen and Hill, Media, Culture and Politics in Indonesia, pp. 200-202.

${ }^{34}$ Michael Maher, Indonesia: An Eyewitness Account (Ringwood: Viking, 2000), pp. 209-210.

35 For details of the trial, see International Commission of Jurists, Report on the Trial of Xanana Gusmao in Dili, East Timor (Geneva: ICJ, 1993).

36 "Pretty Good Privacy" encryption, released publicly on the internet in 1991, enables users to share common "keys," some public and some private, which can be used in transmitting and decoding "scrambled" confidential e-mail messages. PGP is so powerful that it is virtually impossible to break the code of PGPencrypted e-mails without the personal "key." See Moschovitis et al., History of the Internet, pp. 158-159; Kennedy, The Rough Guide to the Internet, p. 121; and http://www.pgpi.org (accessed January 24, 2002). 
conversations that could easily be tapped. The ability to transmit large amounts of information instantaneously had the added advantage of cost efficiency. ${ }^{37}$

Internationally, internet usage was increasing amongst the broader public as the technology became more "user-friendly." The public release in August 1993 of a "clickand-point graphics browser" (that is, one which required a single "click" rather than a string of arcane computer text instruction to activate commands) dramatically simplified internet entry and use, and consumer interest grew accordingly. ${ }^{38}$ By 1994 , a single online service provider, America Online, for example, had four million members, mainly inexperienced, mainstream members of the public. While the vast majority of activists using sources like "reg.easttimor" were users of APC or academic networks, simplified software and expanding network access enabled even computer novices from around the world readily to access a vast array of materials on the Net, including information about East Timor.

TimorNet at the University of Coimbra, Portugal, for example, provided links to information on the history, geography, and culture of the territory, as well as to key UN documents, details of human rights violations, relevant on-line articles and publications, ideas and mobilization advice for activists, news archives, and on-line discussion groups. ${ }^{39}$ One of the most enduring mailing lists to emerge was produced by ETAN/US, 40 which had been catalyzed by the Santa Cruz massacre and had mobilized existing networks and the internet to achieve a nationwide presence, with "a dozen local chapters and several thousands members" by 1996.41 ETAN/US provided e-mailed action alerts on issues such as "the need to lobby congress, severe human rights violations, and the like," with postings averaging about two or three a month. In addition, "reg.easttimor" routinely contained postings from the CNRM, ETAN/US, and support groups in Australia, Portugal, Canada, Ireland, and elsewhere. ${ }^{42}$ "Reports and translations from various wire services, the Indonesian, Portuguese, Australian, British, US and Irish press also regularly appear[ed] there, along with UN and other official documents" totaling about six to ten postings daily. ${ }^{43}$ The site, "reg.easttimor," also provided internet "conference" and "newsreader" facilities, and weekly news summaries. Interested parties could be automatically e-mailed daily updates, or they could elect to receive a newsletter, Network News, of six to ten pages, five times per year, delivered either electronically or in paper. From 1991 to 1995, ETAN/US published a "roughly semi-monthly paper publication," Documents on East Timor, of selected articles from "reg.easttimor"; this publication was mailed to people who did

${ }^{37}$ I would like to thank Ms. Kirsty Sword-Gusmão (who, as a member of the underground, smuggled information between Xanana Gusmão, Ramos-Horta, and others) for discussing use of the internet by activists in these early years. Personal interview, Jakarta, June 12, 2001.

38 Moschovitis et al., History of the Internet, pp. 171-173.

${ }^{39}$ See http:/ / www.ci.uc.pt/Timor/netret.htm (accessed August 10, 2001).

40 Details sourced from http://www.ci.uc.pt/Timor/mlists.htm (accessedAugust 10, 2001).

41 Charles Scheiner, "Grassroots in the Field-Observing the East Timor Consultation," in Bitter Flowers, Sweet Flowers, pp. 109-124, quotation from p. 110. Scheiner was the national coordinator of ETAN/US until August 2001.

42 Renamed east-timor@igc.topica.com, this newsgroup continues to operate with several hundred subscribers around the world. Scheiner, personal communication, September 7, 2001.

${ }^{43}$ Quotation from http://www.ci.uc.pt/Timor/mlists.htm, sighted February 24, 2002. 
not have e-mail access. "By 1995, e-mail access was ubiquitous enough that the paper publication ceased." 44

Internet was enabling pro-East Timor activists from around the world to work collectively, "coordinating closely with East Timorese leaders both inside the occupied territory and in exile, 45 in a focused, accurate manner only previously achieved by governments or large international corporations. For some supporters at least, the very newness and capacity of the medium itself, with the startling advances in communication it offered, engendered a new confidence in their own capacity to organize and mobilize support. The speed, currency, and volume of communication that the internet offered gave activists their own "mass medium" which, in turn, encouraged greater activist response. ${ }^{46}$ Once information-even a snippet smuggled by an individual out of East Timor-was fed into this electronic network, it became further ammunition in the global battle for public opinion. In the commercial media, "accounts of the suffering of the Timorese were sporadic, and rarely came into sharp and sustained focus." By contrast, electronic networking, made possible by internet technology, assisted in maintaining nodes of informed activists and, beyond them, a broader "group of sympathisers ready to respond if and when some development reignited the issue." 47

By 1994, just as "point-and-click" browsers were stimulating a proliferation of organizational and personal "home pages" on the Web, Indonesia itself was being wired to the internet. Initially, this took place via university campuses, but from 1995 commercial ISPs, including the popular wasantara.net established by the national postal system, fanned out across the archipelago. ${ }^{88}$ Activist non-governmental organizations were quick to grasp and take advantage of the technology's potential. Established civil society institutions like the Legal Aid Institute moved quickly on-line. So too did small provincial groups like Yayasan Geni in Salatiga, student-activist fronts like SMID (Solidaritas Mahasiswa Indonesia untuk Demokrasi, Indonesian Student Solidarity for Democracy), and unauthorized labor unions like PPBI (Pusat Perjuangan Buruh Indonesia, Center for Indonesian Workers' Struggle) and the SBSI (Serikat Buruh Sejahtera Indonesia, Indonesian Prosperous Workers' Union), all of whom recognized the political benefits of networking, using the internet as a virtual "news pool" through which they could distribute their materials globally. Among such civil society organizations were a growing number taking up the cause of a free East Timor. From 1991, early supporters included Infight (Indonesian Front for the Defense of Human Rights), Lembaga Penegakan Hak-hak Asasi Manusia (LPHAM, Institute to Uphold Human Rights), and Hidup Baru (the Christian "New Life" organization). By the mid1990s, they were joined by Pijar (Center of Information and Action Network for

\footnotetext{
${ }^{44}$ Personal communication from Charies Scheiner, who published Documents on East Timor (communication September 7, 2001).

45 Scheiner, "Grassroots in the Field," p. 111.

${ }^{46} \mathrm{My}$ thanks to John Waddingham for making this point (personal e-mail, September 5, 2001).

47 Tiffen, Diplomatic Deceits, p. 42.

${ }^{48}$ On the arrival of the internet in Indonesia, see David T. Hill and Krishna Sen, "Wiring the Warung to Global Gateways: The Internet in Indonesia," Indonesia 63 (April 1997): 67-89.
} 
Reform), Yapipham (an inter-religious organization), the Jakarta Social Institute, the Joint Committee for the Defense of the East Timorese (JCDET), and others. ${ }^{49}$

This spreading infrastructure assisted the independence movement, supported by members of the East Timorese underground, many of whom were studying in Java and Bali. Students studying outside of East Timor had long provided a vital conduit for information out of the territory (the Catholic Church and sympathetic "tourists" visiting Timor provided other significant channels for disseminating news) ${ }^{50}$ The expansion of internet facilities increased the underground's effectiveness. An East Timor internet news network was established. Working with Indonesian supporters, learning together to use laptops as mobile internet servers and how to use virtually unbreakable encryption software to maintain secrecy, members of the student underground maintained daily contact with colleagues within East Timor who were feeding out stories of human rights abuses, intimidation and resistance, which then immediately entered the international public domain. ${ }^{51}$ Critical to the ultimate success of the movement was a

complex two-way flow of information and decision-making structures reaching from Cipinang Prison in Jakarta where Gusmão was confined, to East Timor and beyond to CNRT [National Council of Timorese Resistance] external leadership and the ever-increasing numbers of impressive activists and intellectuals emerging from East Timorese diaspora communities around the world. ${ }^{52}$

By 1996, the internet-with mailing lists like apakabar and its local alternativeswas rapidly replacing paper copy and "snail mail" as the dominant mode of communication for at least younger, technophilic activists within this international network. Even for many of the older, more established activists, who were coming to computers late in life with no technical training, there was a growing realization that they should tackle the technology in their human rights work because of the efficiency it offered. There was a widespread appreciation of its potency and its practical usefulness for political lobbying and campaigning, information transfer and dissemination, and public and private communication. Within East Timor, too, the speed and anonymity of e-mail communication contrasted with public fax

49 For a discussion of Indonesian support groups, see George J. Aditjondro, Menyongsong Matahari Terbit di Puncak Ramelau: Dampak Pendudukan Timor Lorosa'e dan Munculnya Gerakan Pro-Timor Lorosa'e di Indonesia (Jakarta: Yayasan HAK \& Fortilos, 2000), pp. 249-260. An earlier English version can be found at http:/ / www.asiet.org.au/reports/gja_pet1.htm (accessed September 3, 2001).

${ }^{50}$ From the early 1980s, underground Timorese student organizations in Java and Bali (like RENETIL) found they had easier access to resources and greater freedom for political discussion and action than their counterparts inside East Timor, who were subject to far greater surveillance and scrutiny. See Constancio Pinto, "The Student Movement and the Independence Struggle in East Timor: An Interview," in Bitter Flowers, Sweet Flowers, pp. 31-41, particularly pp. 33 and 38.

51 Andreas Harsono, "Journalists' use of the Internet bubbled up from underground," Nieman Reports 54,4 (Winter 2000): 74-76, located via http://global.umi.com/pqdweb/ (accessed March 8, 2001). Harsono provides a valuable insider's view of the use of the internet by Indonesian journalists both before and after the fall of Suharto. I would like to thank Charles Scheiner, former National Coordinator, East Timor Action Network/US, for background information on this aspect (personal e-mail communication, March 27, 2001).

52 Richard Tanter, Mark Selden, and Stephen R. Shalom, "East Timor Faces the Future," in Bitter Flowers, Sweet Flowers, p. 246. 
correspondence-which was comparatively exposed and vulnerable to surveillanceparticularly for getting information out of the territory. Such public-access communication was risky, and many young East Timorese activists were arrested and jailed for faxing or phoning out information. ${ }^{53}$ Even in 1997, the quasi-government Telkom office, frequented by the Indonesian military and paramilitary, remained the only public place in Dili from which to send an international fax. ${ }^{54}$ During these latter years of struggle, so pervasive were the new communications technologies that, according to Ramos-Horta, information on the internal situation in East Timor came directly from guerrillas, "written on laptops in the mountains." 55 In July 1999, for example, the military cantonment of Falintil commander Taur Matan Ruak was equipped with satellite phones-by then, ubiquitous-and at least two laptop computers. ${ }^{56}$ But in the campaign for East Timor's independence, the internet was not simply a mechanism for distributing information and exchanging military intelligence. It was a virtual "territory" and battlespace in its own right. It is to this tactical use of the internet as a site for a new form of conflict, or "cyberwar," that we now turn our attention.

\section{"Independence in Cyberspace"}

Twelve months after the Nobel Prize for Peace was awarded to José Ramos-Horta and Bishop Carlos Felipe Ximenes Belo, on the opposite side of the globe to East Timor, The Irish Times reported on November 17, 1997 that:

East Timor might not exist as [a] country due to the Indonesian invasion, but next month it will achieve independence in cyberspace, thanks to an Irish Internet service provider. East Timor's own top-level domain (".tp") has been taken up and registered, and Connect Ireland will administer it in conjunction with East Timorese people currently living here. They intend to hand over the domain to East Timor on independence.

"We are reserving all appropriate names for the future [East Timor] government such as government, subdomain government and all related activities such as education, health etc" a spokesman [sic] for the East Timor Ireland Solidarity Campaign says. The domain's official launch date has been set for December $7^{\text {th }}$, the invasion's anniversary. ${ }^{57}$

\footnotetext{
53 I would like to thank Charles Scheiner for pointing this out, and suggesting Jose Antonio Belo as a wellknown case in point.

${ }^{54}$ Martinkus, A Dirty Little War, p. 43. The author describes the intimidating atmosphere in the Telkom office during his visit in 1997.

55 J. Ramos-Horta, "Site seeing," Guardian, January 11, 1999, p. 12, cited in Chris Mann and Fiona Stewart, Internet Communication and Qualitative Research: A Handbook for Researching Online (London: Sage Publications, 2000), p. 18.

56 Martinkus, A Dirty Little War, p. 247. Taur Matan Ruak had become commander after the death of Konis Santana.

57 "A digital domain for East Timor," The Irish Times on the Web, November 17, 1997, at http://scripts.ireland.com $/$ search $/$ higlig...=/newspaper $/$ computimes $/ 1997 / 1117 / \mathrm{cmp} 4 . \mathrm{htm}$ (accessed March 9, 2001).
} 
In a linked document defining "the social and political aspiration for the East Timor domain," Connect Ireland Project Director Martin Maguire noted that the domain rules "acknowledge our obligations to the people of East Timor, the Diaspora from this country and their continued call for freedom" (italics in the original). Furthermore,

The domain registry and applicants for services under this domain (.tp) hereby affirm East Timor's inalienable, indefeasible, and sovereign right to choose its own form of Government, to determine its relations with other nations, and to develop its life, political, economic and cultural, in accordance with its own genius and traditions.

The domain-name "hostmaster team at Connect-Ireland" was responsible for the domain, which members of the team established "following well established and developed policies and procedures based on Internet standards, on discussions with service providers and network experts both within and outside East Timor, and on experience." 58 What the document did not mention at the time was that the application for the registration of the domain, smuggled into Cipinang prison for approval, designated Xanana Gusmão as the official contact for the domain. ${ }^{59}$ The rules of the Internet Assigned Number Authority (IANA) require, as the technical administrator, someone with an address and telephone line in East Timor, so the application listed the phone number of the barracks of the Indonesian Military Commander in Dili where Gusmão spent his last night in East Timor!60

By 1997, the internet had become such a common venue for the communication of ideas and information between East Timor activists that the claim for an East Timor domain name was a logical assertion of the nation's "virtual" rights, rights vehemently contested by the Indonesian authorities. The Indonesian embassy in London responded that, while Indonesia fully respected the freedom of cyberspace, it was

concerned that this freedom has been misused by Connect Ireland to spread a campaign against Indonesia. The handover of the domain to the government of East Timor is beyond imagination since the government of East Timor will not exist. ${ }^{61}$

\footnotetext{
58 The East Timor Top Level Internet Domain (.tp), located at http:/ /www.nic.tp/etrules.htm (accessed March 9, 2001).

${ }^{59}$ Simon Hayes, "Push to give Timor control over domain," The Australian, February 13, 2001, p. 42. The email address for the administrator was apparently xanana@minihub.org (conversation with Kirsty SwordGusmão, Jakarta, June 12, 2001).

${ }^{60}$ William Hederman, "Internet recognition for East Timor," The Irish Times, December 6, 1997, located on http://www.freedom.tp/struggle.htm (accessed September 7, 1999). The registration of the domain name may have been important symbolically, but it had attracted only one host by January 1999. See Moschovitis et al., History of the Internet, p. 280, which provides a table of "Top-Level Domain names by Host Country." East Timor's low host numbers for ".tp" contrast starkly with the commercially attractive domain name for the largely unknown South Pacific island state of Niue, with 1,608 hosts. This popularity was primarily due to Niue's memorable domain tag, ".nu," which means "now" in Norwegian, Danish, Swedish, and Dutch. For details, see "A digital domain for East Timor," The Irish Times on the Web, November 17, 1997, at http://scripts.ireland.com/search/higlig...=/newspaper/computimes $/ 1997 / 1117 / \mathrm{cmp} 4 . \mathrm{htm}$, (accessed March 9, 2001).

${ }^{61}$ Hederman, "Internet recognition for East Timor."
} 
The internet strategies of the pro-independence movement were beginning to bite. Adverse internet publicity was alarming the Indonesian military. East Timor commander, Colonel Slamet Sidabutar, used the occasion of a visit by the US military attaché on August 13, 1997 to stress to the news media that security in East Timor was not as oppressive as depicted in internet news. ${ }^{62}$ Internet coverage of East Timor was also worrying members of Indonesia's Parliament (Dewan Perwakilan Rakyat, DPR), some of whom urged the government to open up the territory to European mass media "so they do not need to take information about East Timor from the NonGovernmental Organizations which often have a negative perception of Indonesia." B. N. Marbun, a member of the DPR and of the National Commission on Human Rights (Komnas HAM), advocated opening the territory because "We have to counter the negative influence of East Timor news in Internet." 63 The Indonesian government was recognizing the adverse potential of the internet as a source of information and was casting around for strategies to counter it. In the hands of civil society activists, the internet offered more than just a rapid method of distributing information. Maximizing the Net's political impact was becoming an activist art in itself, with considerable potential for escalation.

\section{Hacktivism as Political Strategy}

Dorothy Denning, in a paper examining the internet as a tool for influencing American foreign policy, identified three broad classes of internet-related activism:

The first category, activism, refers to normal, non-disruptive use of the Internet in support of an agenda or cause. [This] includes browsing the Web for information, constructing Web sites and posting materials on them, transmitting electronic publications and letters through e-mail, and using the Net to discuss issues, form coalitions, and plan and coordinate activities. The second category, hacktivism, refers to the marriage of hacking and activism. It covers operations that use hacking techniques against a target's Internet site with the intent of disrupting normal operations but not causing serious damage. Examples are Web sit-ins and virtual blockades, automated e-mail bombs, Web hacks, computer break-ins, and computer viruses and worms. ${ }^{64}$ The final category, cyberterrorism, refers to the convergence of cyberspace and terrorism. It covers politically motivated hacking operations intended to cause grave harm such as loss of life or severe economic

62 "Internet undermines E Timor Security Situation," Antara, August 15, 1997, located via a search of http://global.umi.com (accessed March 8, 2001).

63 "MP suggests opening up E Timor to European Mass Media," Antara, September 10, 1997, located via a search of http:/ /global.umi.com (accessed March 8, 2001).

${ }^{64} \mathrm{~A}$ "virus" is a "code designed to infect computers and replicate itself by using other programs or data, either for no meaningful reason (a prank) or with malicious intent," while a "worm" is a self-replicating program which can spread from computer to computer within a network without requiring users to activate it. Moschovitis et al., History of the Internet, pp. 136 and 294. 
damage. An example would be penetrating an air traffic control system and causing two planes to collide. ${ }^{65}$

Since 1997, East Timor activism on the Net had included actions which fit into Denning's second category, with cyber-attacks becoming increasingly common. Information (including dis-information) placed on a website by either party in an international conflict was open to hacking and manipulation. In 1997, hackers ${ }^{66}$ breached several official Indonesian government websites, posting pro-independence messages and linking them to pro-independence websites. By May 1997, (as reported by the South China Morning Post) the Indonesian government was "waging war against a new breed of freedom fighter for East Timor-the computer hacker." 67 With the netname "Toxyn," a hacker from the group "Portuguese Hackers Against Indonesia" breached the military's website and scrawled "propaganda" across it. Breaches had already occurred to the sites of the Department of Foreign Affairs, the IPTEK government computer system, the Indonesian Institute of Studies, and the Surabaya Institute of Technology, according to Indonesian computer guru Onno W. Purba of the Bandung Institute of Technology's Computer Network Research Group. The penetration of the military site was quickly rectified, but hacktivism had become a proven strategy in the East Timor struggle. So substantial and so frequent were the anti-Indonesian government hacks of 1997 that the campaign (along with breaches of NASA, the British Conservative Party, and the Spice Girls websites) was declared one of the "Hacks of the Year" in an international survey of the past quarter-century's computer milestones. 68

On July 11, 1998, Portuguese hackers known as "kaotik" penetrated the Department of Security site, replacing it with the slogan "Free Xanana Gusmao." They declared,

This attack is not against indonesian [sic] people but against its government and their opression [sic] towards the republic of Timor. These actions were made to

65 Dorothy E. Denning, "Activism, Hacktivism, and Cyberterrorism: The Internet as a Tool for Influencing Foreign Policy" (Washington, DC: Georgetown University, 2000), http://www.nautilus.org/infopolicy/workshop/papers/denning.html (accessed March 15, 2001).

66 The term "hacker" was originally coined in the early 1960 s by computer programmers at the Massachusetts Institute of Technology to refer to programmers who were passionately dedicated to the belief that "information-sharing is a powerful positive good," and who shared their computer expertise "by writing free software and facilitating access to information and to computing resources wherever possible"; the connotation of the word was meant to be positive. In the mid-1980s, the media popularized the term as a pejorative for computer criminals such as virus writers. This led hackers to coin the uncomplimentary term "cracker" to differentiate those imbued with the "hacker ethic" from "criminal hackers." See Pekka Himanen, The Hacker Ethic and the Spirit of the Information Age (London: Secker \& Warburg, 2001), esp. pp. vi-vii, which cites The Jargon File at www.tuxedo.org/ esr/jargon. This paper uses "hacker" in its original sense.

67 Jenny Grant, "Guerilla Hackers take on Military," South China Morning Post, May 3, 1997, at http://www.infowar.com/hacker/hackza.html-ssi (accessed March 15, 2001).

68 "Looking Back...," Computing Canada, June 12, 2000, p. 6, sourced through http:/ / web2.infotrac.galegroup.com (accessed March 9, 2001). The Indonesian Government sites were apparently hit repeatedly on January 19 , February 10, April 24, June 30, and November 22, 1997, while the other sites were only attacked once: NASA (March 5), UK Conservative Party (April 27), and Spice Girls (November 14). 
honour and remember all the 250 people killed in Dili on the12November [sic] 1991. WE DONT [sic] FORGET WHAT THEY HAVE DONE !!!!!69

Over the first two days of August this same group hacked forty-five Indonesian domains, in what appears to be one of the largest single co-ordinated hack-attacks ever. ${ }^{70}$ In a media interview, one member of the group in his early twenties, known only by the hacker name "Secretos," outlined the group's political agenda: "We have hundreds of servers we could hack, and we don't. [ . . . ] The main objective of our hacking pages is to transmit the message [of East Timor independence]. It is not, 'We are groovy, we have power."'71 For "kaotik," cyber-attack was part of a broader political strategy.

The Toxyn attack triggered a revenge strike by a group dubbed the "Indonesian Street Fighters" who claimed to have crashed Toxyn's server (although Toxyn denied this, countering that they were simply "down" while upgrading). What appears to be another group, "IndoHack," reportedly attempted to attack the Portuguese server, but was unsuccessful. In another counter attack, "ByteSkrew" succeeded in penetrating the server of Portugal's University of Coimbra, which hosted TimorNet Information Service..$^{72}$ The attacks were part of a growing hacking culture developing in Indonesia, in which the practitioners dubbed themselves "electronic cockroaches" (kecoak elektronik). But some of the young Indonesian hactivists who were initially hostile, above all towards Portugal, gradually changed this position. According to one report on the kecoak elektronik homepage, exchanges of abuse between Toxyn and ByteSkrew softened into an "alliance" between them as the Portuguese explained their political perspective. The article by a self-confessed hacker concluded that the majority of Indonesian young generation hackers "are anti-establishment and anti-oppression. And a tyrannical government like Indonesia is justifiably seen as the enemy by them." 73 Portuguese hackers' criticism of Suharto's folly in East Timor seemed to elicit sympathy from Indonesian hackers caught up in the growing mood of domestic opposition to the President in late 1997 and 1998.

However, despite the Reformasi movement in Indonesia, which forced Suharto to step down on May 21, 1998, internet attacks against pro-East Timor sites continued, with some highly coordinated and, in the opinion of opponents, officially sanctioned. When "cyberspace saboteurs" forced the ISP Connect Ireland off line in January 1999, the company, which had been acting as a server for sites using the East Timor domain name, suspected that this campaign had official Indonesian backing. It protested to the Indonesian Embassy in London. Connect Ireland Project Director, Martin Maguire, stated that their servers had come under systematic attack from at least ten different

\footnotetext{
69 The hacked page can be viewed at http://www.kaotik.org/98/hankam1.html (accessed March 15, 2001).

70 Details of the forty-five servers hacked are given on http://www.kaotik.org/98 (accessed March 15, 2001).

71 Quoted in Amy Harmon, "Hacktivists of All Persuasions Take their Struggle to the Web," http://www.kaotik.org/98/nytimes1.html (accessed March 15, 2001).

72 http:/ / www.uc.pt/scripts/timornet/sirius.exe/etmp?index.html (accessed January 24, 2002).

73 Chiko Torremendez,"Situasi perhackingan indonesia[sic]," located at http:/ / www.kelektronik.org/ezine/situasi.htm (accessed March 27, 2001).
} 
sources in a strategy he believed was organized by the Indonesian government. The attacks, over more than nine months, were not directed at a single website, but at the top level domain for East Timor, ".tp." In what was described by one Irish newspaper as "the most sophisticated [cyber-attack] ever recorded in this country," eighteen separate hackers apparently operated in unison throughout the night of January 19 to break into Connect Ireland's security system. Maguire believed "the attack was so well organised, so deliberate and so skilful that whoever was doing it must be getting paid. The value to them is not one of kudos." 74 Indonesian authorities denied any involvement in the incident, but Maguire persisted in his suspicions, claiming "It's a regime that has shown little regard for human life. Attacking an Internet service would not be outside their moral boundaries."75 After the attack, Maguire declared "we received support from many Indonesians-who translated our statement(s) [sic] into the many languages that are used within that territory and circulated these widely."76 The incident attracted extensive international attention in the mainstream print and electronic media, and Maguire was inundated with "some 14,000+ email offering support."77 If the attack on Connect Ireland had been officially sanctioned, the President of Indonesia was clearly not aware of it, for Habibie had already informed his Ministers on New Year's Day that he would accept independence for East Timor if that was the outcome of a "popular consultation." This dramatic shift was announced publicly by Foreign Minister Ali Alatas and Information Minister Yunus Yosfiah on January 27, eight days after Connect Ireland temporarily shut down. ${ }^{78}$

On April 21-23, 1999, the Indonesian proposal was formally presented at talks with Portugal and the UN Secretary-General, to be formally signed off on May 5 with a "popular consultation" agreed for August. ${ }^{79}$ An Australian Parliamentary inquiry noted that in East Timor "human rights abuses decreased [after Suharto's resignation] and security forces did not interfere with public rallies and demonstrations in major towns." The presidential transfer had inspired a greater boldness amongst the proindependence students and the underground resistance, but, as the inquiry added, "this more tolerant approach did not last long and serious abuses became more frequent from late 1998." ${ }^{80}$ The prospect of a referendum injected a new uncertainty. While, for its part, Falintil observed a unilateral ceasefire, militias-transparently created, funded, armed, and directed by the Indonesian military-attempted to

\footnotetext{
${ }^{74}$ Maguire is quoted by Caroline O'Doherty, The Examiner Front Page, January 23, 1999, located on the East Timor Ireland Solidarity Campaign site. (This article was provided to me by John Waddingham.)

75 Information on the Connect Ireland attack is given in "Hackers rob East Timor of cyberspace independence," at http://asia.internet.com/Reuters/1999/01/2801-news.html, and Brian McWilliams, "Irish Provider Blames Failure on Other ISPs" on http:/ / www.internetnews.com/ispnews/print /0,1089,8_63651,00.html, (both accessed September 5, 1999), and "Press Release from ConnectIreland Communications Ltd" at http://www.freedom.tp/press.htm (accessed September 7, 1999). Maguire is quoted in McWilliams.

76 Martin Maguire in "Press Release-from Connect-Ireland Communications Ltd."

77 Information from Martin Maguire, e-mail communication, March 13, 2001.

78 See Parliament of the Commonwealth of Australia, East Timor: Final Report, p. 178.

79 The initial date of the "popular consultation" was to be August 8, 1999, but it was postponed to August 30.

${ }^{80}$ Parliament of the Commonwealth of Australia, East Timor: Final Report, p. 89.
} 
terrorize the UN into abandoning East Timor and to intimidate the population so that citizens would be afraid to cast pro-independence votes in the referendum. ${ }^{81}$

Amidst this heightening terror, even as the United Nations Mission in East Timor (UNAMET) prepared for the ballot, the internet battle for East Timor took a new turn. On August 17 Ramos-Horta reportedly threatened to unleash a "desperate and ferocious" internet campaign if Indonesia refused to honor the results of the August 30 referendum. He claimed more than one hundred computer hacktivists had prepared a dozen special computer viruses capable of bringing Indonesia to a standstill for weeks by infecting electronic communications systems, including aviation. It was an assertion doubted by many, including some close to Ramos-Horta. But, in Denning's terms, this was a threat to escalate from hactivism to cyber-terrorism. It was reported that Ramos-Horta claimed that hackers, mostly teenagers in Europe and the USA, stood ready to attack Indonesia's banks, stock exchange, and government computer systems. ${ }^{82}$ Indonesian officials declared they would take "preventative action" against Ramos-Horta's threats, which they viewed as "extremely serious" and which were referred to the Ministry for Political and Security Affairs. Dino Patti Djalal, a senior official in the Indonesian Foreign Ministry, was quoted declaring, "This is terrorism against democracy." 83

Martin Maguire, victim of the Connect Ireland hack, quickly disassociated his organization from Ramos-Horta's tactic, declaring that

we do not condone attacks of any kind on the Internet or other similar technologies. We believe in the freedom of speech and in everyone's ability to conduct their communication for their own legitimate purposes. We [... ] believe there is more to be gained by maintaining the opportunities that can be developed through free speech than in conducting cyberwarfare. ${ }^{84}$

But the sense that "Indonesia may be on the brink of a cyberwar" was growing within some sections of the country's political elite, as the leading English-language Jakarta Post editorialized that

the employment of the Internet for political expression and conflict is an inevitable consequence of the information revolution.[ ... It is indicative of

81 There were, for example, fifty-seven people killed in Liquiça on April 6 with a dozen more murdered in Dili on April 17. See Parliament of the Commonwealth of Australia, East Timor: Final Report, p. 179. See also Martinkus, A Dirty Little War, pp. 116-262, where the author describes this period graphically.

82 Lindsay Murdoch, "Computer chaos threat to Jakarta," Sydney Morning Herald, August 18, 1999 , p. 9.

This source was used by David Legard, "Cyberwar threatens Indonesia," The Standard, dated August 19, 1999, located at http://www.thestandard.com/article/article_print/0,1153,5962,00.html (accessed March 29, 2001).

83 Lindsay Murdoch, "Fury over computer threat," Sydney Morning Herald, August 20, 1999, p. 8. This source was used by Nancy Weil, "Indonesia Answers Hacker Threats," The Standard, August 19, 1999, located at http://www.thestandard.com/article/display/0,1151,5978,00.html (accessed March 29, 2001).

84 "Press Release_from Connect-Ireland Communications Ltd." (August 19, 1999) located at http:/ / www.freedom.tp/press.htm (accessed September 7, 1999). 
cyberspace that a territory the size of East Timor is at the center of what has become a global issue, and has attracted participants worldwide. ${ }^{85}$

There is nothing to indicate that Ramos-Horta ever acted on his threat, even during what he dubbed "the darkest days of my life" during the post-referendum violence. ${ }^{86}$ Irrespective of whether he was able technologically to unleash the attack, to do so may well have been judged diplomatically counterproductive. Of her three categories of internet activism, Denning had noted, "There is a general progression toward greater damage and disruption from the first to the third category, although that does not imply an increase of political effectiveness." 87 It may be that, just as Gusmão stayed Falintil's hand-limiting its activities to certain designated cantonments rather than risk civil war and withdrawal of international support for the referendum in the face of murderous militia provocation-so too, in the final instance, Ramos-Horta judged a cyber-attack on Indonesia would only weaken his nation's moral claim that the situation in East Timor merited international military intervention.

Nonetheless, as the diplomatic temperature increased in the weeks prior to the referendum, cyber-terrorism-at least at the level of threat-had become another strategy in the East Timor conflict. That referendum and its traumatic aftermath highlighted the pivotal role new communication technologies were playing in media reporting and international responses to the crisis.

\section{Referendum and New Technologies}

With large numbers of observers and journalists arriving in the weeks before the referendum, getting information out of East Timor by internet, or any other means, took patience and determination. The single ISP in East Timor was the national postal service's wasantara.net, operating only in Dili. 88 When the world's largest organization of journalists, the Brussels-based International Federation of Journalists, and two of its key Asian affiliates, the Alliance of Independent Journalists in Indonesia and the Media, Entertainment, and Arts Alliance in Australia, opened a Safety Office for Media in East Timor (SOMET), its e-mail address was somet@dili.wasantara.net.id. ${ }^{89}$ Despite the general reliance on an over-stretched wasantara.net, the internet had become an integral part of a converging, if still rudimentary, local media. For example, prior to the referendum, Fretilin's radio station Radio Vos de Esperance took much of its

85 "East Timor Cyberwar On New Global Battlefield: The Internet," The Jakarta Post, August 30, 1999, located at http://www.infowar.com/mil_c4i/99/mil_c4I_083099b_j.shtml (accessed March 13, 2001).

86 The intense strain between the September 4 declaration of poll results and the September 13 acceptance by President Habibie of a UN peacekeeping force, as Ramos-Horta lobbied relentlessly for international intervention, is documented in Tom Zubrycki's film, The Diplomat (produced by Sally Browning for Film Australia, Lindfield, 2000). The Ramos-Horta quotation is from Tony Parkinson, "Ramos-Horta: The inside story," The Age, August 28, 2000, located at http://etan.org/et2000c/august/27-31/28ramos.htm (accessed August 28, 2001).

87 Denning, "Activism, Hacktivism, and Cyberterrorism."

${ }^{88}$ See [Indonesia-1] "KIPER-Sulitnya Telekomunikasi di Timor Timur," located on http:/ / www.indopubs.com/archives/0627.html, dated August 30, 1999, but accessed September 3, 1999.

89 "IFJ launches safety office for journalists in ET," dated August 7, 1999, located at http:/ / etan.org/et99b/august/1-7/5ifj.htm (accessed March 10, 2001). 
news from internet sources, which it then translated into the local Tetun language for broadcast. The broadcaster's reliance on the internet continued until the station was forced to close and its operators to flee into the bush. ${ }^{90}$

Existing telecommunications infrastructure remained basic, with phone land lines scarce and inadequate. Most ordinary citizens had to rely on rare and poorly equipped public access telephone kiosks (wartel), of which districts such as Baucau only had three-one run by the quasi-government Telkom and two private kiosks. Mobile cell phones had become increasingly popular in the preceding years. For interested parties ranging from key student activists to militia leaders, the "handphone" had become a reasonably common accessory, at least in Dili and in the one or two other major centers in which they functioned. However, the two Indonesian mobile phone companies, Telkomsel and Satelindo, were unable to cope with the booming demand from consumers, a situation that led to a complete log-jam on occasions when demand exceeded network capacity. Key players such as Falintil continued to rely on satellite phones, for example, to report atrocities to the International Committee of the Red Cross. ${ }^{91}$

Many of the outsiders who flooded the territory to facilitate and observe the referendum brought their own mobile communication equipment. Members of the international media, and even individual election monitors or observers, were able to maintain voice or internet contact with their organizations, via satellite or mobile phones, albeit with somewhat frustrating coverage. After a visit to Gleno, about thirty kilometers south-west from Dili, the head of the Australian Observer Delegation, Tim Fischer, observed "Local communications were next to zero even though telephone or mobilenet links existed, although mainly for the area around Dili." 92 International monitoring teams in the field, like IFET (International Federation for East Timor), for example, depended on satellite phones (though land lines were available in Dili where the IFET office had six). It was through such links that organizations like IFET accessed the internet (via Indonesian servers) and communicated with the outside world. News of militia atrocities was rapidly transmitted around the world via satellite video link, often from the roof of Dili's Mahkota Hotel, which functioned as a virtual studio for the international media who "had brought in container loads of equipment for their satellite links back to their home newsrooms."

Attacks on the general population continued to escalate, with a significant pause on the referendum day itself. By September 1, 1999, some Dili residents were seeking the relative security of the UNAMET compound. On September 4 , the retaliatory offensive against the independence movement went into high gear, with buildings

\footnotetext{
90 Solahudin et al., Ganasnya Satgas, Kejamnya Milisi Timtim: Laporan Kekerasan terhadap Jumalis dan Media Massa Mei 1999-April 2000 [The Ferociousness of Satgas, The Cruelty of East Timor Militia-A Report on Violence towards Journalists and Mass Media May 1999-April 2000] (Jakarta: AJI Indonesia, 2000), pp. 14-15.

91 See, e.g., Martinkus, A Dirty Little War, p. 106.

92 Tim Fischer, Seven Days in East Timor: Ballot and Bullets (Sydney: Allen \& Unwin, 2000), p. 46.

93 Ibid., p. 36. Fischer provides several examples of how communication by mobile phone enabled the media (and the Australian government) to get direct reports from East Timor during the Popular Consultation. See ibid., pp. 69, 76, 94.
} 
burned in large numbers throughout the territory. By mid September, 300,000 refugees were in hiding within East Timor, and another 150,000-this number eventually swelled to 250,000-were herded across the border into West Timor. ${ }^{94}$ The world watched the security of East Timor unravel before its eyes. In the days after the referendum, international radio and television stations were conducting "live to air" phone and video-link interviews with personnel, even those held virtual hostage in the surrounded UNAMET compound. Journalist John Martinkus wrote of the UNAMET compound at the close of the first week of September

the regular phone lines were cut off, and mobile phones started working only occasionally and only on a certain network. Satellite phones had become the only real means of communication with the outside world ... [We] found out later that the whole UN contingent had been relying on three satellite phones for communication with the outside world. ${ }^{95}$

For the independent Indonesian media covering the referendum and its aftermath, the challenges were equally overpowering. ${ }^{96}$ When the Indonesian government declared a state of martial law in East Timor on September 7, 1999, as the military-backed militia razed the territory and virtually depopulated Dili, Indonesia's largest daily newspaper, Kompas, took the unusual step of informing readers that, under the relevant 1959 legislation (UU Nomor 23/Prp/1959 tentang Keadaan Bahaya) the

... military emergency authorities, among other things, have the right to control all postal infrastructure and telecommunications equipment, such as telephones, telegraph, radio transmitters, and other equipment which is related to radio broadcasting and which can be used to reach the general population. ${ }^{97}$

As Kompas warned its readers, "the military emergency authorities have the right to 'censor' the news which will be filed by journalists who are currently still in East Timor," for all printed material was similarly subject to military control. Many Indonesian media staff were effectively intimidated during this period. But despite such regulation, the internet, combined with the vastly more accessible medium of broadcast radio, continued to be employed by some Indonesian media organizations to disseminate non-government information about East Timor within Indonesia. After the

94 Initial figures are estimates provided by the UN's humanitarian coordinator for East Timor, Ross Mountain, on September 19, 1999. Cited in John G. Taylor, East Timor: The Price of Freedom (London: Zed

Books \& Annandale: Pluto Press Australia, 1999), p. 229. Taylor provides a detailed chronology of the main events in East Timor since 1974 on pp. 200-230. The figure of 250,000 comes from a later Amnesty International document, "Annual Report 2000: Indonesia and East Timor," at http:/ / www.web.amnesty.org/web/ar2000web.nsf/countries/a8b2dcbe3c6cac35802568f200552930? OpenDocument (accessed September 24, 2001).

95 Martinkus, A Dirty Little War, pp. 321, 324.

96 Indonesian journalists were routinely harassed and assaulted. A reporter with Indonesia's largest daily newspaper, Kompas, only survived being shot by five bullets on August 26 because of his bullet-proof jacket. A month later, his compatriot, Agus Mulyawan (working for the Japanese agency, Asia Press International), was murdered at close range after identifying himself as an Indonesian journalist at a militia ambush on the Los Palos-Leuteum road. A survey of atrocities against journalists-East Timorese, Indonesian and others-is given in the bi-lingual publication Solahudin et al., Ganasnya Satgas, Kejamnya Milisi Timtim, particularly pp. 13-28.

97 See [Indonesia-1] "KMP-Di Timtim telepon pun akan dikuasai militer," datelined September 8, 1999, and quoted here from http://www.indopubs.com/archives/0796.html (accessed September 8, 1999). 
militias drove most journalists from the territory and after arrival of the International Force for East Timor (InterFET) on September 20, Jakarta-based independent Radio $68 \mathrm{H}$ continued to receive reports from freelancers in East Timor. These reports, transmitted from the field via internet or mobile phone, were repackaged and distributed by the Radio $68 \mathrm{H}$ to 150 stations in its network across Indonesia, using both internet and radio transmission. ${ }^{98}$ Suspicions that anti-independence hackers were active resurfaced in Jakarta on the day the UN evacuated all but eighty-four of its staff from its compound, leaving Dili (in the words of a departing Portuguese journalist) "a ghost city." 99 On the afternoon of Friday, September 10, the Jakarta Post website's opinion poll mysteriously crashed. The poll, which asked whether Indonesia should invite an international force into East Timor, had registered 3,720 votes before crashing, with a staggering 94 percent in favor of an international deployment. Faced with the inexplicable site crash, the Editor could only announce "our IT people are still trying to find out the cause. [ . . ] We regret the inconvenience."100

While all forms of media coverage of the referendum and subsequent pillage of East Timor contributed to the considerable weight of international public opinion, the wellestablished activist internet networks provided a powerful infrastructure for the dissemination of up-to-the-minute information on unfolding events. As one observer noted:

East Timor was the first country born of the Internet Age, thanks to the sophisticated information bombardment of its committed supporters. [. . . ] Part of the reason for the turn of events in September 1999 when President Clinton and Prime Minister Howard relented to armed peacekeepers going to East Timor was the level of Internet outrage on embassy systems at the White House, in Portugal, and the Australian Parliament."101

It was a view endorsed by Ramos-Horta, who declared the ultimate acceptance by President Habibie of an international force "illustrates the power of the media, the power of images, the power of the Internet." 102 He believed "it was the weight of world public opinion-and shame-that finally liberated East Timor."103 In turning this shame into a political victory, and in mobilizing international political and military support, the internet has proved a sophisticated tool. It is also proved to be a vital means of communication during the period of reconstruction.

\footnotetext{
${ }^{98}$ For details on Radio $68 \mathrm{H}$, see www.radio68h.or.id, and Jeanne Carstensen "Internet Radio," Whole Earth (Spring 2000): 89, located via http://web2.infotrac.galegroup.com/itw (accessed March 9, 2001). 99 Quoted in Taylor, East Timor, pp. 228-229.

$100 \mathrm{http}: / /$ www.thejakartapost.com:8890/iscp_render?menu_name=frontpage (accessed September 13, 1999).

101 Bernadette Connole, "Irony in the Pacific for long-distance diplomat," The Australian, June 26, 2000, located at http://etan.org/et2000b/june/25-30/26irony.htm, (accessed March 10, 2001).

102 Quoted in Parkinson, "Ramos-Horta: The inside story."

103 Ramos-Horta's position is noted in Mark Chipperfield, "Keeping the issue alive," in East Timor: Making Amends? Analysing Australia's Role in Reconstructing East Timor, ed. Lansell Taudevin and Jefferson Lee (Sydney: Otford Press, 2000), pp. 145-147, quotation from p. 147.
} 
Indonesia's scorched-earth policy left the territory without most basic infrastructure. In post-referendum East Timor, one of the early logistical requirements of both the military peacekeepers and the international non-governmental organizations was the establishment of secure, reliable internet and e-mail communication. The United States InterFET contingent insured secure internet access to their Defense Department's classified network for military information. ${ }^{104}$ Following the experience of the US military, which in 1995 began linking its overseas service personnel with their home bases and families via internet in what was dubbed "Operation Home Front," InterFET quickly set up an internet café for its staff in Dili. ${ }^{105}$ Oxfam International/ Community Aid Abroad quickly linked their Dili field office by e-mail to the rest of their international organization abroad. ${ }^{106}$ Local community and religious organizations (like the Carmelites) established their own internet connections, initially using superseded computers from aid dispatches (described by one journalist as "old stuff that might ordinarily be destined for the scrap yard"). ${ }^{107}$ The technological and internet savvy of international supporters continued to play a role. The East Timor Institute for Reconstruction Monitoring and Analysis, La'o Hamutuk (Walking Together), for example, was set up to "monitor, to analyze, and to report on the activities of the principal international institutions present in Timor Loro Sa'e [... and] to facilitate greater levels of East Timorese participation in the reconstruction and development of the country." 108 In producing its regular bulletins and e-mail updates, this local initiative was assisted by ETAN/US through its homepage at www.etan.org/lh/.

The advantages of internet connectivity for the new state were quickly espoused, with Ramos-Horta declaring in February 2000 that his country would turn to the internet to generate trade and investment as it integrated with the world. ${ }^{109}$ Having witnessed the power of the internet during the long years of struggle, Ramos-Horta was well placed to recognize its potential benefits for an independent East Timor. He observed:

104 Bill Murray, "U.S. peacekeepers use Net to access classified network," Government Computer News 19,11 (May 15, 2000): 40, downloaded via http:// web2.infotrac.galegroup.com/itw on March 9, 2001.

105 Moschovitis et al., History of the Internet, p. 206. The author gives details of Operation Home Front. See also Alan Ryan, "Primary Responsibilities and Primary Risks": Australian Defence Force Participation in the International Force East Timor, Study Paper No. 304 (Duntroon: Land Warfare Studies Centre, 2000). This source includes a photograph of the InterFET internet café between pp. 66-67.

106 Charlie Brady and Gordon Rowell, "Email to Dili-you have got to be joking!," at http://www.caa.org.au/groups/IT/dili, (accessed March 13, 2001).

107 Eric Ellis, "Asia Buzz: Making a Difference Connecting nuns in East Timor to the Internet," Time Asia, January 4, 2001, located on http:/ /etan.org/et2001a/january/01-06/04conn.htm (accessed March 10, 2001). Ellis describes helping the Carmelite Convent in Comoro, outside Dili, download e-mails using a Darwin ISP. He says, of their enthusiasm, that "Within 30 minutes, the nuns had 50 new sites in their 'favourites' list and were busy sending e-mails around the world."

108 Quoted from http:/ / www.etan.org/lh/, (accessed August 14, 2001).

109 "Horta Sees Internet Future for East Timor" (accessed February 20, 2000), at http://www.cnn.com/ 2000/ASIANOW/southeast/02/13/timor.internet.reut/index.html, cited in Justin Yap, "The Internet and the Knowledge Economy: Charting a Course in Cyberspace," unpublished paper written for the Harvard Project for Asian and International Relations Conference, Beijing, August 2000. 
In this global economy, you don't have to have really an enormous space and population of your own. [ . . . ] You sit at the computer and you trade anywhere around the world. You can buy, you can sell, just at the touch of a keyboard. We are part of the global economy [ . . . and] as a small nation we have to look at the world through the Internet, meaning surf the rest of the world for business opportunities to sell, to buy, to invest. ${ }^{110}$

Establishing that connection to the global economy proved challenging. Commercial or individual users of the internet (who might not have a laptop and mobile phone modem) were soon able to use an Australian Telstra Internet room in Dili, but the hefty charge of about five Australian dollars for fifteen minutes was prohibitive for virtually all East Timorese. ${ }^{111}$ Nor was it easy to convert East Timor's earlier claim to "independence in cyberspace" into a reality, as negotiations with Connect Ireland for the transfer of authority over the ".tp" domain name proved prolonged and, as yet, inconclusive. ${ }^{112}$ The Australian Domain Authority (AuDA) stepped in to offer its technical and hosting assistance to help East Timor get ".tp" under its control, though the issue remains unresolved. ${ }^{113}$ East Timor does not yet have its own listing in the widely used internet search engine Yahoo.com's "Countries" sub-directory. ${ }^{114}$ Meanwhile, the East Timor Transitional Administration (ETTA) website, www.gov.east-timor.org, is on an American domain, such as is used by the United Nations, with a "mirror site" in Malaysia. Many other websites related to East Timor are hosted by the UN, UNDP, the World Bank, and international NGOs.

In this transition to independence, ETTA is actively seeking potential internet service providers for East Timor, which currently lacks its own. ETTA's policy is that "there should be regulation with a light touch aimed at ensuring the protection of the customer (quality of service; privacy), adherence to the principles of fair competition and network integrity." 115 ETTA is calling for tenders for a "Build Operate and Transfer project for the construction and operation of a complete Telecommunications system for East Timor," with the successful tenderer promised an exclusive license for

${ }^{110}$ Ramos-Horta is quoted in Chris Johnson, "Interview: Horta sees Internet future for E.Timor [sic]," February 13, 2000, and located at http://etan.org/et2000a/february/13-19/13interv.htm (accessed March 10, 2001).

111 Australia's national Telstra mobile phone network operates in East Timor. On the local irritation at Australian "carpet-baggers" there, see Conor O'Clery "Timorese leaders plan nation-building," The Irish Times on the web, August 28, 2000, located via http://scripts.ireland.com/search (accessed March 9 , 2001).

112 Connect Ireland denied reports from within East Timor that negotiations had stalled, stating it was still "working towards moving domain activities to Dili" and indicating that "a location will be identified in the coming months." Martin Maquire, personal e-mail, October 30, 2001.

113 Simon Hayes, "Push to give Timor control over domain," The Australian, February 13, 2001, p. 42.

114 Excellent sites on East Timor include: Timor Today at http://www.easttimor.com (accessed March 10, 2001) and the East Timor Action Network/United States site at

http://www.etan.org/resource/websites.htm (accessed March 10, 2001). The search of yahoo.com, <http://dir.yahoo.com/Regional/Countries/> was conducted on March 12, 2001.

115 Quotations in the paragraph are from East Timor Transitional Administration, "Criteria for Operation as an Internet Service Provider in East Timor," last updated August 6, 2001, located at

http://www.gov.east-timor.org/itpt/isp_criteria.php (accessed August 13, 2001). 
ten years. Significantly, the provision of internet services is explicitly excluded from this exclusive license, and, according to the proposed agreement, after a maximum transitional period of three years there will be "full liberalisation of the ISP market." Prospective ISPs are warned that "only a small number of the population has, at present, access to computers. Moreover their computer skills are very low. Although this is likely to change quite rapidly in the future it is not expected that the development will be immediate."116 With East Timor's illiteracy rate of at least 15 percent (and possibly as high as 50 percent), and an economy and infrastructure in tatters, it is likely to be some time before the internet in peacetime plays as important a role for the people of East Timor as it has during the struggle for independence.

\section{Conclusion}

Timor Loro Sa'e might not yet have established itself as a contender in the commercial world of the internet, but the internet as a mechanism for exerting international political leverage upon Indonesia has proved its value. As MSNBC Washington correspondent Brock Meeks reflected in early 1998:

The slaughter of innocents in East Timor might get forty-five seconds on the network news and two minutes more on MSNBC or CNN. And then, as a news story, it dies. However, take that same story to the Internet and it not only lives, it proliferates, millions of times a day. It refuses to die. It refuses to go unnoticed. And when enough people generate enough talk, generate enough letters to enough of the right people, things start to happen. This is the power of the Internet.117

It was a power mobilized to unanticipated effect by supporters of an independent East Timor. But it was not the technology of the internet that sustained an international campaign for East Timor. The technology was simply employed by activists who would (and did), in its absence, struggle to gain and wield diplomatic and political leverage, using whatever technologies were at their disposal. In this articulation with a range of other technologies-"new" and "old" - the internet takes its place as a powerful tool in the service of civil society.

We can only speculate on the effect such a tool may have had in triggering Indonesia's policy shifts, but in reflecting upon the lessons of her East Timor foreign policy debacle, one of Indonesia's most senior former spokespeople mused, "we should not underestimate the power of NGOs to influence government policies." 118 In the complex interplay between military strategies and political leverage, many factors contributed to the ultimate success of the movement for self-determination in East Timor. Chisako M. Fukuda has noted, among other elements, the importance of the guerrilla forces in symbolically maintaining the Timorese fighting spirit and identity, the contribution of Indonesia in creating an educated (but ultimately under-utilized and frustrated) youth who consequently "gravitated to the forefront of the resistance

116 Ibid.

117 Brock Meeks, "No justice, no peace," Association for Computing Machinery. Communications of the ACM 41,2 (February 1998): 17-19, located via a search of http://global.umi.com (accessed March 8, 2001).

118 Statement (made under Chatham House rules) at a conference on Australian-Indonesian Relations sponsored by the Centre for Strategic and International Studies, Jakarta, March 23, 2001. 
movement," and the decisive leadership of Gusmão in initiating strategic shifts from armed guerrilla conflict, to underground resistance and non-violent civil protests. ${ }^{119}$ Ultimately, however, Fukuda argues that a "commitment to nonviolence came first and foremost in building the self-reliance of the resistance movement,"120 and that this was crucial in enabling leverage to be exerted over Indonesia, both internationally and domestically, through sympathetic human rights and pro-democracy organizations.

For the first fifteen years, before the internet, such civil society organizations used "snail mail," telephone, and fax to sustain their campaign for East Timor's selfdetermination. Internet and e-mail were articulated almost unconsciously into the activists' armory, so surreptitiously that some of the most active in the campaign have difficulty recalling precisely when they adopted the evolving technologies of what Manuel Castells has labeled the "informational mode of production."121 But, equally, the technology itself may not have been merely incidental. As one long-time Australian activist mused,

... the new media were TOOLS (which enhanced the effectiveness of activism/resistance) rather than stimulating/causing political work. But was there something in the one-off 1990s novelty/new-ness/wonder of the medium itself which offered/stimulated, outside immediate resistance and activist circles, a broader direct engagement with the Timor story (and which ultimately had a political impact)? And even among activists, did not the medium engender a confidence-building increased sense of power? I suspect it did. ${ }^{122}$

In the final years at least, "Access by independent eye-witnesses to instantaneous communication media-cell phones, satellite transmissions, Internet-based networking-made it possible to generate widespread public awareness and conviction in 'realtime': that is, while such awareness could still make a difference."123

Barney Warf and John Grimes have argued that "The Internet obviously does not guarantee the emergence of counterhegemonic discourses, but it does facilitate the opening of discursive spaces within which they may be formulated and conveyed."124 The way the internet was mobilized in the cause of East Timor supports this conclusion. The Net enables individuals and local groups to draw effectively upon skills and resources from supporters located far away. It can focus international attention on events that local authorities are attempting to keep secret and deny an enemy access to their data or communications systems through hactivist attack or even

${ }^{119}$ Chisako M. Fukuda, "Peace through Nonviolent Action: The East Timorese Resistance Movement's Strategy for Engagement," Pacifica Review 12,1 (February 2000): 17-31. Quotation from p. 19.

120 Ibid., p. 25.

121 Manuel Castells, The Informational City: Information Technology, Economic Restructuring, and the Urban-Regional Process (Oxford: Blackwell, 1989); and The Rise of the Network Society, vol. 1 of the series, The Information Age: Economy, Society and Culture (Oxford: Blackwell, 1996).

122 John Waddingham, co-founder/editor of Timor Information Service (1975-84), personal e-mail communication, September 9, 2001.

123 Huntley and Hayes, "East Timor and Asian Security," p. 183.

124 Barney Warf and John Grimes, "Counterhegemonic discourses and the Internet," Geographical Review 87,2 (April 1997): 259-274, located via a search of http://global.umi.com (accessed March 8, 2001). 
cyber-terrorism. However, ultimately, the most dramatic effects of the internet and other new electronic communication technologies, as Castells notes, are "in the realm of symbolic politics, and in the development of issue-oriented mobilizations by groups and individuals outside the mainstream political system."125

125 Manuel Castells, The Power of Identity, vol. 2 of The Information Age: Economy, Society and Culture (Oxford: Blackwell, 1997), p. 352, quoted in Warf and Grimes, "Counterhegomonic discourses and the Internet." 
